\title{
新生児の包茎に対する包皮翻転指導
}

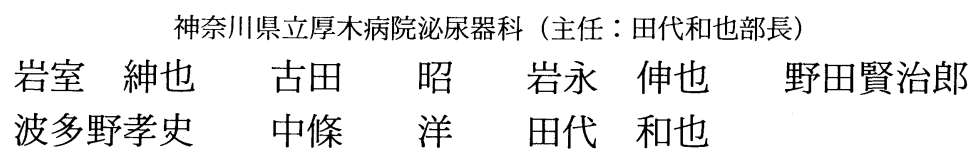

\section{FORESKIN RETRACTION FOR PHIMOSIS OF THE NEWBORN}

Shinya Iwamuro, Akira Furuta, Shinya Iwanaga, Kenjirou Noda,

Takashi Hatano, Hiroshi Nakajo and Kazuya Tashiro

Department of Urology, Kanagawa Prefectural Atsugi Hospital

(Chief: Kazuya Tashiro)

(Background) No guideline exists on how to treat boy's phimosis. We examined if retraction of the foreskin of the newborn boy's penis could make true phimosis become false phimosis.

(Methods) We taught the mother to retract the foreskin and keep inside the foreskin clean. Exposure degree of glans by retraction of foreskin was defined in 7 grades, 0 (none) III (middle) $\sim$ VI (full).

(Results) Of the 538 newborn examined, none had full exposure (VI). All of the 372 cases who continued the procedure, including 2 buried penis, gained full exposure (VI). Average time for full exposure according to the first degree of exposure was 2.94 months (0), 1.78 months (III), 1.22 months (V), 2.32 months average, respectively. No serious complications occurred.

(Conclusion) Retraction of the foreskin from the newborn period made all the true phimosis to be false phimosis and operative procedures became unnecessary.

Key words: phimosis, foreskin retraction, new born

要旨：(背景と目的)新生男児の大半は包茎であるが，包茎に関しては明瞭な治療指針がない．われわれ は新生児期から包皮を翻転し，包皮内の清潔を保つ指導をすることで亀頭部を露出できる可能性につい て検討した。

（対象と方法）1994年 1 月より1995年10月の間に当院で出生した男児の母親に対して新生児期からパ ンフレットとビデオで包茎と包皮翻転指導の有用性について説明した後に泌尿器科医が母親に対して包 皮翻転指導を実施した。指導内容は1）無理のない範囲で包皮を翻転し，ガーゼ等で包皮内面や亀頭部を 陰茎根部に向かって拭く，2）包皮の翻転はおむつを替える度と入浴時に行う，3）操作後は包皮を戻す を原則とした。包皮翻転の進捗状況は 1 カ月健診時に泌尿器科医がチェックし, 亀頭部が完全に露出で きる状態を完了とした。

（結果）初診時の亀頭部の用手的露出度を不可（０）～亀頭部中間（III）～完全（VI）の 7 段階に分類 した. 新生児538例中, 亀頭部を完全に露出できるVI 度の症例はなかった.しかし, 包皮翻転指導を行っ た結果,継続的に経過観察し得た372例は埋没陰茎の 2 例を含め全例亀頭部を完全に露出することができ た. 亀頭部が完全に露出できるまでに要した期間は，0 度は平均 2.94 月， III 度は1.78月，V 度は1.22月， 全体の平均 2.32 月であった。指導に伴う特記すべき合併症はなかった。

（結論）新生児期から包皮を翻転し亀頭部を露出する指導を徹底することで，真性包茎状態の新生児 でも経過観察できた全例が仮性包茎となり，手術を回避することが可能になると思われた. キーワード : 包茎, 包皮翻転指導, 新生児 
表 1 指導内容（ビデオ・パンフレット）

1. 包莰とは

1) おちんちんの構造

2）真性包茎と仮性包茎の違い

2. 包皮翻転の目的

1）包皮内の清潔の保持

2）真性包茎の予防による手術や龟頭包皮炎の回避

3. 包皮翻転の方法

1）無理のない範囲で包皮を翻転し，ガーゼ等で包皮内面 や渑頭部を陰茥根部に向かって拭く

2）包皮の翻転は扔むつを替える度と入浴時に行う

3）操作後壮包皮を戻寸

4. 包皮翻転の注意点

1）軽度の出血があっても心配しないで清潔にする

2）軽度の出血があっても翻転を続ける

3）嵌頓包茎の予防方法(包皮口が亀頭部を越えて戻らな くなった場合, 包皮を伸展し包皮口(狭い所)を直接 持って亀頭部を挟むように引くと戻る)

5. 包皮翻転完了後の日常生活の注意点

1）子供が自分自身で包皮の翻転と清潔保持ができるまで は保護者がする

2）子供が自分自身で包皮の翻転と清潔保持ができるよう に指導する

3）子供が自分自身で排尿できるようになったとき虫包皮 を翻転して排尿することを習慣づける
緒言

新生児にとって包茎は生理的な状態であり, 従来, 日本では積極的な処置をすることはなかった。しかし， 最近は乳幼児期の健診で包茎を指摘されるなど，小児 期に包茎を主訴として医療機関を受診する患者は少な くない ${ }^{112)}$. 小児期の包茎の定義や対応方針は医師に

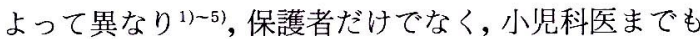
が混乱するところとなっている，今回われわれは，新 生児期から包皮を翻転する指導をすることで，新生児 期, 乳児期の包茥が全例龟頭が露出可能な状態になり 得るか，すなわち，手術を回避し，なおかつ容易に清 潔を保つことができるかについて検討した。

\section{対象と方法}

対象は1994年 1 月より1995年10月の間に当院で出生 し，3 月月以上経過観察し得た男児538人であった。

包皮翻転指導は男児の母親に対して実施した。まず 出産の翌日にビデオ及びパンフレットで包茎と包皮翻 転指導の目的，方法等について説明した(表 1 )。次に 母親の入院中に泌尿器科医が 2 回程度母親に対して包 皮翻転指導を実施した。包皮翻転の進捗状況は小児科 での児の 1 カ月健診時に併せて泌尿器科医がチェック

図 1 用手的龟頭部露出度

包皮を翻転し亀頭部の露出を試み，全く亀頭部が露出できないのを 0 度，亀頭部の中間をIII度，龟 頭部を冠状满まで完全に露出できるのをVI度とし，それぞれの間を 2 段階ずつに分けた。

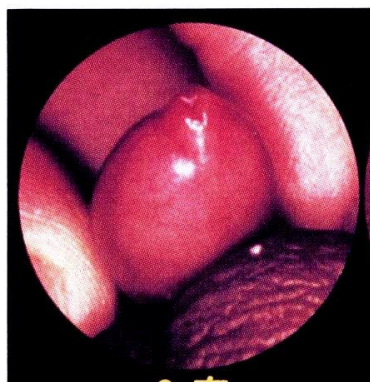

0 度

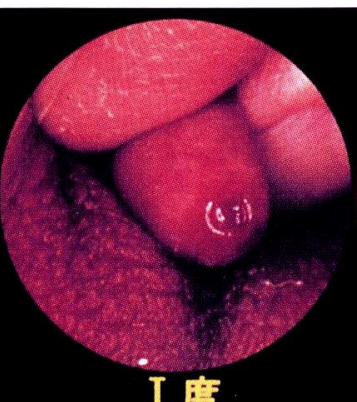

I 度

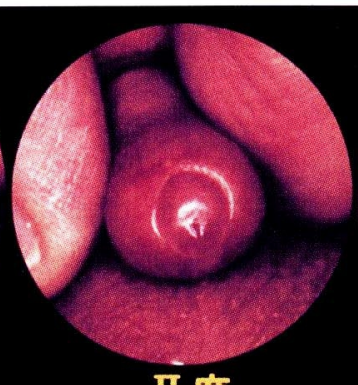

II 度

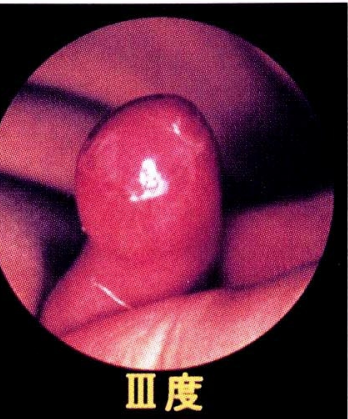

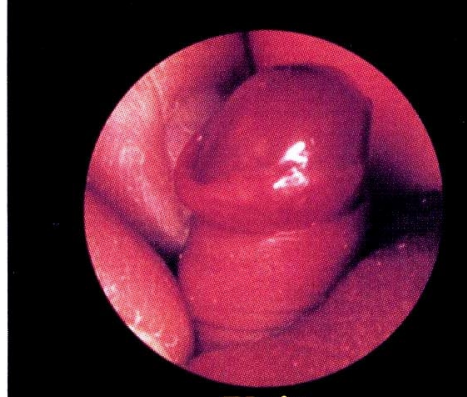

N 度

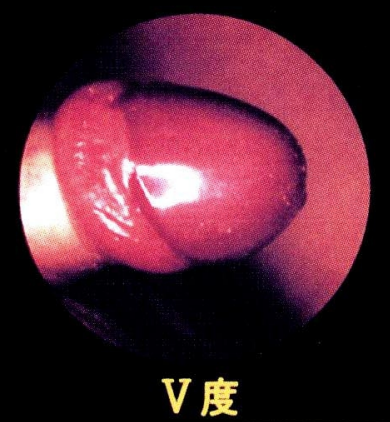

V 度

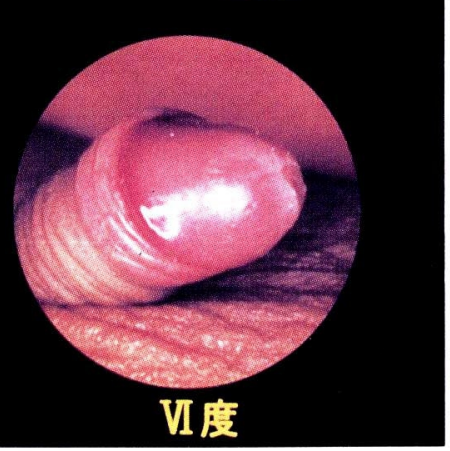


図 2 初崄時（新生児）嵌頓包茎例

（左・中央）初診時，（右）整復 1 日後
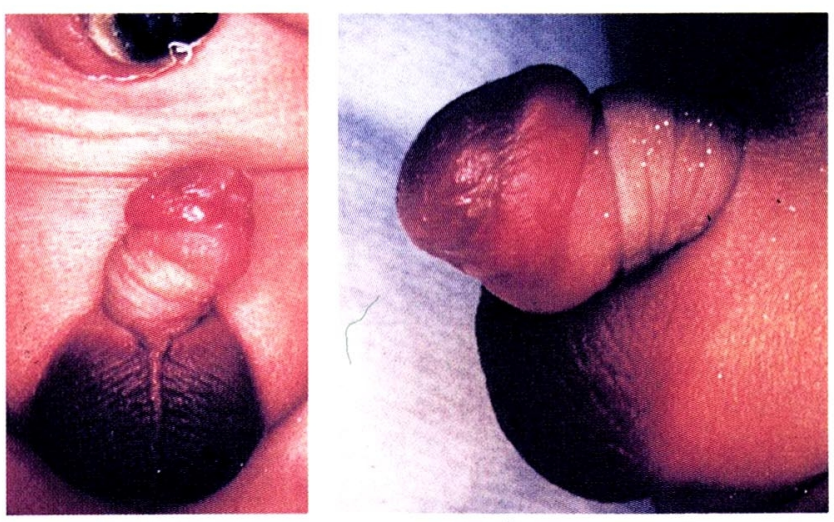

表 2 包皮翻転指導結果

\begin{tabular}{c|c|c|c|c|c|c|c|c}
\hline $\begin{array}{c}\text { 用手的亀頭部 } \\
\text { 露出度 }\end{array}$ & 0 & I & II & III & IV & V & VI & $\begin{array}{c}\text { 合計 } \\
(\%)\end{array}$ \\
\hline \begin{tabular}{c} 
初 診 時 \\
\hline (对 全 数\%)
\end{tabular} & 75 & 215 & 175 & 38 & 15 & 20 & 0 & 538 \\
\hline 完 了 & 53 & 132 & 124 & 32 & 13 & 18 & 0 & 372 \\
\hdashline (対初診時\%) & $(71)$ & $(61)$ & $(71)$ & $(84)$ & $(87)$ & $(90)$ & & $(69)$ \\
\hline 平均所要月数 & 2.94 & 2.57 & 2.21 & 1.78 & 1.35 & 1.22 & 0 & 2.32 \\
\hline
\end{tabular}

した.

泌尿器科医による用手的亀頭部露出度の判定基準を

(図 1 ）のごとく7段階に分類した。「龟頭部が完全に 露出でき, かつ嵌頓包茎の危険性がない状態」を指導 完了とした。1 力月時に亀頭部を完全に露出できない ケースは親の希望があれば泌尿器科外来で亀頭部が完 全に露出できるまで，1 1 月毎に来院指導した。外来 では必要に応じて抗生物質含有軟高を処方した。

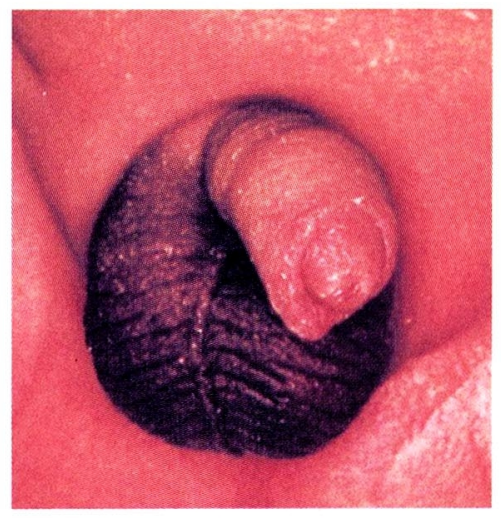

結果

指導開始前の包皮を翻転しない状態では, 全く龟頭 部が見えなかったのが527例 (98.0\%), 龟頭部の一部 露出を認めたのが11例 $(2.0 \%)$ であった。そのうち 1 例は新生児の嵌頓包茎であった（図 2 ). 包皮翻転指導結果を（表 2 ）に示す.

指導開始前の初診時の用手的亀頭部露出度は 0 度 $14 \%$, I 度 $40 \%$, II 度 $33 \%$, III度 $7 \%$, IV度 $3 \%, \mathrm{~V}$ 度 $4 \%$ であった．初診時から亀頭部を完全に露出でき るVI度の症例はなかった。

埋没陰茎は 2 例あり用手的龟頭部露出度は 0 度と I 度（図 3 ）であった。

龟頭部が完全に露出できるまで診察と指導を継続し 得たのは 372 例 $(69 \%)$ で，最短 1 日，最長 6 力月，平 均 2.32 月で埋没陰茎 2 例を含む全例が龟頭部を露出で きた。亀頭部が完全に露出できるまでの平均所要月数 は 0 度2.94月，I 度2.57月，II度2.21月，III度1.78月， IV度1.35月，V度1.22月であった。

図 3 埋没陰茎の指導結果

（左）非翻転時, (中央) 指導開始前用手的亀頭部露出度（I 度), (右) 指導完了時用手的亀頭部露 出度 (VI度)
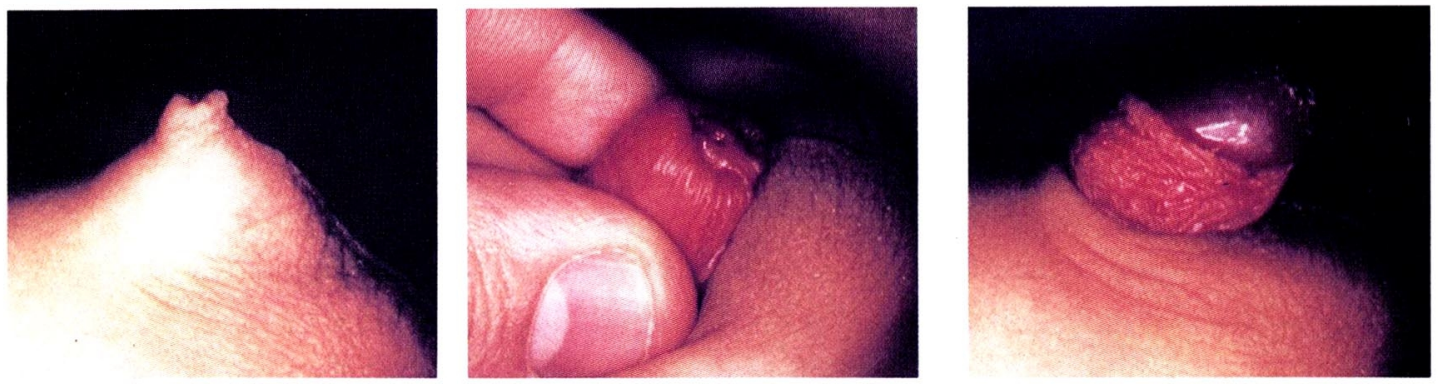
亀頭部が完全に露出できるまで通院しなかった脱落 例は166例（31\%）であった。

亀頭部が露出できた 372 例のうち外尿道口が 1 ～ 2 $\mathrm{mm}$ 後退した亀頭部尿道下裂を 5 例認めた。恥垢は程 度の差はあったがほぼ全例に認めた。

包皮翻転指導に伴う合併症としては退院後嵌頓包茎 となり電話で相談をした例が 2 例あったが， 1 例は電 話の指導で母親が整復し，1例は受診させた上で整復 した。新生児の嵌頓包茎例を含め, いずれの症例も最 終的には包皮口が十分伸展し嵌頓する危険性がない状 態になった。その他には包皮翻転指導に伴う重篤な合 併症はなかった。

\section{考 察}

包茎は医学的には真性包茎と仮性包茎に分類されて いるが，その定義についての明確な基準はない. 川村 ${ }^{11}$ は『成人における「真性」,「仮性」の分類の仕方は小 児では適応できない』, 高橋2) を出そうと包皮をずり下げても露出できないものを真 性包茎, 包皮口が狭くなく容易に露出できるものや包 皮内板と亀頭部の一部が癒着し, 亀頭部が一部しか見 えないものも含めて仮性包茎に入れる』としている. 今村 ${ }^{5}$ は包茎を『包皮内板と亀頭が癒合しているもの で，用手で尿道口が出にくい，あるいはわずかに見え るもの』とし，その率は $1 \sim 3$ カ月児で $87 \% ， 3$ 歳児 $34 \%$ と報告している．今回われわれの検討では，新生 児では亀頭部を冠状溝まで完全に露出することができ る症例は 1 例もなかった。しかし, 亀頭部が露出しに くいとされる「埋没陰茎」(図 3 ) や「とっくり型」3) (図 1：0度）を含め, 包皮翻転指導を継続し得た症例は すべて冠状溝まで亀頭部を露出できる状態になること が明らかになった。このVI度の状態, すなわち亀頭部 が完全に露出でき，かつ嵌頓包茎の危険性がない状態 を「仮性包茎」, それ以外の状態 $(0$ 度〜 V度) を「真 性包茎」とし，包皮の翻転を繰り返すことで「真性」 も「仮性」になり得ることも併せて周知徹底すること が必要であると思われた。なお，龟頭部を完全に露出 できる状態にする必要はないとの意見も考えられる が，中途半端な指導では嵌頓包茎を起こす危険性もあ り, 冠状溝まで露出した状態を確認している.

小児の包茎に対する手術適応は医師により異なる が, 小児泌尿器科領域では, (1)包皮口狭小による排尿 障害, (2)再発性亀頭包皮炎, (3)嵌頓包茎の用手還納後 再発予防が多く,これらの他に再発性尿路感染や両親, 患児の希望を入れる場合がある1 ${ }^{1) 4)}$. 今回の検討では
表 3 小児期の包茥の対応方針の問題点

\begin{tabular}{|c|c|c|}
\hline & 包皮翻転指導 & 手 術 治 療 \\
\hline 子 供 の 負 担 & 小さい & 大きい \\
\hline 処 置後の形態 & 自 然 & 人工的 \\
\hline 親の理解の獲得 & \multicolumn{2}{|c|}{ 比較的容易 } \\
\hline 親 の 負 担 & 大きい & 小さい \\
\hline 麻 & なし & 全身麻酔 \\
\hline リ & なし & あり \\
\hline 医 & 低 額 & 高 額 \\
\hline 医師のコンセンサス & 今後の課題 & 比較的容易 \\
\hline
\end{tabular}

嵌頓包茎の既往がある症例も包皮翻転指導により全例 手術が必要でない仮性包茥の状態にすることが可能で あり，嵌頓包茎の既往は絶対的な手術適応にはならな いと思われた。伊藤ら ${ }^{3)}$ は用手的に包皮翻転を試み，翻 転不能例を手術適応としている，松岡ら ${ }^{4}$ は包皮が用 手的に翻転できない真性包茎は尿路感染の面からも 3 歳前後に手術を行うのが妥当であるとしている.また, 近年，包茎は思春期以降の男子の大きな悩みで6)，仮 性，真性を問わず手術を希望するケースが少なくない. しかし，他院で 3 歳で手術をし亀頭部が常に露出した 状態になった症例が友人と比較して外観が異なること で悩み，保育園に通園できない例もあった。

小児期の包茎の対応方針の問題点を包皮翻転指導と 手術治療で比較した(表 3 ). 子供の負担が少ない，処 置後の形態が自然である，麻酔や手術に伴うリスクが ない等の点から包皮翻転指導が望ましい. 小児期の手 術は本人の希望ではない場合がほとんどであり，包荎 の治療に関して明確な対応方針が確立されていない現 状では手術やその後の問題を回避するために，健診等 で包茎を指摘され2)31，手術を受ける前に少なくとも仮 性包茎の状態にしておくことは意味があると思われ た.

包皮翻転指導の問題点は医学的側面と社会的側面の 2 つに分類された(表 4 )。医学的には, 合併症として の出血，亀頭包皮炎，嵌頓包茎が考えられる．われわ れは親に不安を与えないため, 出血は最小限にした。 特に亀頭部腹側の包皮小帯は出血しやすいので主に亀 頭部背側を剝離するように指導した，亀頭包皮炎は処 置時の清潔に気をつけ，2 カ月以上経過観察をした症 例で，積極的に包皮を剥離した場合は予防的に抗生物 質含有軟膏を処方することで問題となる亀頭包皮炎は なかった．今後は，手術適応や包皮翻転指導について の医療者の意思統一が課題であると思われた.

社会的には，両親，家族の理解を得ることがもつと 
表 4 包皮翻転指導の問題点

医学的側面

1. 合併症 (出血, 亀頭包皮炎, 嵌頓包茎)

2. 包茎の手術適応の不統一

3. 医療者 (泌尿器科医, 小児科医, 小児外科医, 看護職, 等)の意志統一

社会的側面

1. 両親・家族の理解

2. 社会的合意の形成

3. 指導者の確保

4. 指導時間の確保

5. 指導に伴う医療費の保証

も重要であった.対象者の $31 \%$ では指導を継続できず, その理由として里帰り分婏のためも少なくなかった が，包皮翻転指導の必要性が母親本人を含め家族に十 分理解されなかったことも一因と考えられた。父親や 祖父母から「かわいそうだ」と言われたと相談する母 親もあり，1力月健診時には一緒に来ている家族全員 に有用性を説明し, 指導をするようにしている。逆に 父親が包茎について悩んでいた場合は積極的な協力が 得られた。新しい試み故に今後他の施設や地域で指導 を展開する場合は社会的な合意を形成し, 指導者を確 保することが課題であると思われた，当院では年間約 300 人の男児が出生するが, 病棟や健診時に指導に要し た時間は 1 人あたり $2 \sim 3$ 分， 1 回に $3 \sim 10$ 人で約 10〜30分であった。包皮翻転指導は乳幼児の健康診断 のように医療費の保証はなく， 1 週間に 1 時間半程度 の時間ではあるが診療時間を確保し継続的に指導を実 施する体制の確立が課題である，外来での診療は親子 の負担を軽減するため診療開始時間の前の 30 分間を当 てている.

大多数の包茎は放置していても自然に包皮が翻転で きるようになるため包皮翻転指導を行うにしても，新
生児ではなく幼小児期から開始するとの意見もある. しかし，わずかな刺激や痛みでも生後 6 か月以降では 寝返りを打ち，1歳以降では包皮の翻転を拒否する場 合が少なくなく指導が困難になる，指導開始年齢とし ては新生児期が最も容易でかつ適当であると思われ た。

\section{結 語}

1. 新生児期に亀頭部を完全に露出できる子供はい なかった。

2. 新生児, 乳児の包皮翻転指導で，一見真性包茎で あっても平均 2.32 月で亀頭部を完全に露出できる仮性 包茎になった。

3. 包皮内の清潔を保ち, 真性包茎の手術を回避する ためにも新生児期からの包皮翻転指導は重要であると 思われた。

4. 今後は泌尿器科医による保護者に対する指導が 徹底されることが望まれる。

\section{文献}

1）川村 猛：包茥. 小児科，34，1401-1408，1993.

2）高橋 剛：包茎·癿頭包皮炎. 臨泌, 48, 132-136, 1994.

3）伊藤泰雄, 韮澤融司, 薩摩林恭子, 田中裕之, 長谷 川景子，関 信夫：小児包茎の治療方針と手術適 応. 日臨外医会誌，54，631-635，1993.

4）松岡弘文, 梶原一郎, 田原春雄, 大島一寛：小児尿 路感染症および膀胱尿管逆流に扔ける発生要因と しての包茥の意義. 日泌尿会誌，85，953-957， 1994.

5）今村榮一：乳幼児の包茎. 小児科診療, 57, 23392344, 1994.

6）内田美代子, 加藤きく代, 岡本登美子, 小山厚子, 折井亜子, 番内和枝, 岩室紳也, 北村邦夫, 米沢 宏：オープン八ウスによせられる男性の悩みへの 対応一電話相談抢よびクリニックから一。 思春期 学, 10, 247-251, 1992.

（1996年2月8日受付，9月9日受理） 